Journal of Economics and Behavioral Studies

Vol. 2, No. 6, pp. 286-297, June 2011

\title{
Inward Investment and Market Structure in an Open Developing Economy: A Case of India's Manufacturing Sector
}

\author{
Jatinder Singh \\ Centre for Economic Studies and Planning, Jawaharlal Nehru University, New Delhi \\ jatindercds@gmail.com
}

\begin{abstract}
India announced series of liberalization measures since mid 1980s that inter-alia led to an unprecedented increase in the inflow of foreign direct investment (FDI). Evidence suggests that the rising inflows of FDI have influence on host country market structure though the direction is uncertain. Analytically, market structure has implications on the long run growth path of an economy through its effect on the allocation of economic resources among various economic activities including innovation. In this context, the objective of this paper is to analyze the bearing of FDI on market concentration with special reference to India's manufacturing industries during the post-reform period. The study made use of firm level and product level data and panel regression techniques to fulfill the objective. The estimated model has shown a positive and significant influence of FDI on market concentration. If the result of the study is any indication, the increased inflow of FDI is likely to make India's manufacturing sector more concentrated and calls for policy measures to mitigate undesirable outcomes of FDI inflows.
\end{abstract}

Key Words: FDI, Market Structure, Economic Reforms, Technological Capabilities, Market Concentration

\section{Introduction}

The issue of industrial concentration have attracted the attention of many academicians and policy makers since long (Ghosh, 1975; Curry and George, 1983; Kambhampati, 1996) mainly owing to the economic inefficiencies and negative welfare implications attached to it. A renewed interest in industrial concentration, however, have come to prevail in the recent times, owing to opening up of the many traditionally closed economies, and rapidly increasing cross-country mobility of capital, labour, intermediate goods and final goods. However, many countries which have remained closed till recently have been viewing this process of global integration with cautious optimism ${ }^{1}$. Among others, one of the apprehensions of globalization in these economies had been the domination of foreign firms and their capture of domestic markets (Singh, 2009; Yun, 2001).

In the Indian context, globalization signifies a paradigm shift in the institutional structure of industrial regulation ${ }^{2}$. From a closed regime of licensing policies, rigid capacity controls, administrative prices and restricted entry of foreign firms (Joseph, 1997) and such other state sponsored measures to regulate sellers market concentration in manufacturing sector in the pre-reform era (Athreye and Kapur, 2006), India has travelled a long way. The major policy shifts since the 'New Economic Policy' in July 1991 involved the removal of industrial licensing policy, removal of restrictions on Foreign Direct Investment (FDI) and repealing of the Monopolies and Restrictive Trade Practices (MRTP) Act of 1969, opening of reserved sectors, among others. These liberalisation measures have facilitated the entry of FDI through Multinational Corporations (MNCs) to India at an unprecedented rate. For instance, the total FDI inflow increased from US $\$ 0.08$ billion in 1991 to about US\$ 41.55 billion in $2008^{3}$ (UNCTAD, 2009). During this period (1991 to 2008), manufacturing sector has attracted 34.09 per cent (or $\$ 14.16$ billion) of total FDI inflow into India (Secretariat for Industrial Approval, 2009).

Existing studies observe that the rising inflow of FDI, however, has implication on the evolution of industrial market structure in host country (Yun, 2001; Dunning and Lundan, 2008). The reform package introduced in nineties was aimed to promote competition and improve efficiency in Indian industrial structure by ensuring business friendly environment in the economy (Handbook of Industrial Policy and Statistics, 2001). Against 
this background, the basic research questions for empirical verification are as follows (i) how do such large volumes of FDI inflow affect the Indian market structure? (ii) Does it enhance competition or does it exacerbate industrial concentration? These are the fundamental questions which this research paper has tried to address. This study acquires further relevance due to the fact that no systematic attempt has been done till date in India on this important issue though such studies have been conducted in other countries (Lall, 1979; Lundin, Sjoholm and Qian, 2007; Dunning and Lundan, 2008) ${ }^{4}$ and it has immense relevance for competition policy in India. However, the issue of market structure and other related aspects like its bearing on innovation (Bhaskar, 1992; Subramanian, 2005) firm performance (Giarratana, Pagano and Torrisi, 2003, Pant and Pattanayak, 2005; Beena, 2006) and others (Kumar, 1990; Nair, 2008; Pushpangadan and Shanta, 2008) have attracted the attention of scholars, the influence of FDI on market structure, despite its immense policy relevance, is yet to receive the attention that it deserved. The paper is divided into five sections including the introduction. Section two offers a brief review of existing literature on the issue at hand. Methodology and data sources used in this study are presented in section three. Estimates of the model are discussed in section four followed by concluding remarks in the last section.

\section{FDI and Market Structure: A Brief Review}

To understand the complexity of the issue at hand, paper broadly divides literature into two sub-sections: (i) Theoretical literature (ii) Empirical literature.

Insights from Theoretical Literature: It has been shown that the nature ${ }^{5}$ of industry where Transnational Corporations (TNCs) are entering are fundamental to the understanding of the influence of FDI on market structure (UNCTAD, 1997; Haller, 2004). If MNCs are entering in a highly concentrated industry via greenfield investment, the immediate impact of the entry of MNCs will be an increase in the number of firms in the industry which is more likely to provide competition to the existing market leaders. But the long run effect of FDI on market structure will depend on competitive strength and technological capabilities ${ }^{6}$ of host country firms (Blalock and Gertler, 2009). Technological capabilities (technical, managerial and organizational skills) are firm specific and evolve over time through experience and purposeful investment made by the firm in technological up-gradation. If domestic firms have attained the minimum threshold level of capability, they will further enhance those capabilities through various types of investment linkages with MNCs, vertical transformation of technology and technology spillovers (Sutton, 2007). In this regard, the technology gap between local firms and MNCs gets reduced and a competitive market structure might emerge. Contrary to this, if technology gap is widening between local firms and MNCs due to poor absorption capacity of local firms then entry of MNCs will crowd out the local investment and consequently market concentration will increase in the long run (Joseph, 1997; Haller, 2004). The theoretical understanding makes it clear that the influence of FDI on local industrial structure is heterogeneous and outcomes are directly linked with the existing knowledge base and the degree of flexibility in the production process.

Empirical Literature: The issue of FDI and its bearing on market structure has empirically been well studied area of research in case of different developed and developing countries (Lall, 1979; Lundin, Sjoholm and Qian, 2007; Dunning and Lundan, 2008). But, the findings are inconclusive. There is a set of empirical literature on FDI and host country market structure, which made out the strong case by showing the evidence that the entry of MNCs reduced market concentration and improved competition in the host country industrial market structure. The study by Kindleberger (1969) reveals that the entry of MNCs transformed host country market structure into competitive market. Similarly, Cho (1990) tested the impact of FDI on banking market structure in Indonesia during 1974 to 1983 . The study used $\mathrm{N}$-firms concentration ratio as a measure of concentration. The empirical findings have supported the view that foreign presence reduced market concentration (after controlling the impact of other variables). This in turn is likely to happen in those industries or countries where local market leaders have created artificial entry barriers for new entrants. Driffield (2001) examined the impact of inward FDI on industry concentration in UK's manufacturing sector for the period of 1983-92. Using econometric technique, the study indicated that the entry of MNCs reduced concentration and promoted competition in U.K.'s manufacturing industry. The recent study in the Chinese context used firm level data for the period of 1998-2004 and found that the entry of MNCs reduced concentration. The study suggested the strong and robust negative impact of FDI on firms' price cost margin 
(after controlling for efficiency). This meant that FDI led to increase in competition in Chinese manufacturing sector (Lundin, Sjoholm and Qian, 2007). Other studies, namely Braunerhjelmon and Oxelheim (1999); Markusen and Venables (1997); Petrochilos (1989) also showed that entry of FDI diluted the market power of the local firms.

Contrary to the above studies, Lall (1979) studied the impact of MNCs presence on the Malaysian manufacturing sector. The empirical results revealed that the high foreign presence was associated with high level of concentration. Bourlakis (1987) also analyzed the influence of entry of MNCs on Greece manufacturing industries for the period of 1975 to 1979. The evidence implied that the presence of MNCs promoted market concentration in Greece. Newfarmer (1979) explored the positive association of FDI and industrial concentration in Brazilian industry. Paper particularly noted that MNCs used predatory pricing strategy to get dominant position in the market. Blomstrom (1986) found that MNC presence acted as an independent source of concentration in Mexico and Willmore (1989) presented similar results for Brazil. The study by Yun (2001) carried out a similar exercise for Korean manufacturing sector during 1991 to 1997. The empirical findings specified that the entry of MNCs had positively contributed to industrial concentration and subsequently raised the price cost margin. However, all the cited literature above suggests that the influence of FDI on host country's market structure varied across countries and industries. The discussion clearly states that the entry of MNCs promoted competition especially in developed countries. It is so because the domestic firms in those economies have already accessed modern methods of production and are able to compete with MNCs by improving upon the existing capabilities. On the other hand, most of the developing countries have experienced high concentration with the entry of MNCs with China being the only exception. MNCs possessed ownership advantages that enabled them to perform better than their counterpart firms in host country. In this process, MNCs wipe out competition and consequently exacerbates market concentration.

\section{Data and Method}

For empirical investigation, the study collected data from two secondary sources published by the Centre for Monetary Indian Economy (CMIE). The first dataset - Industry, Market size and Share - provides information for sales, import and export at product level for some selected products in manufacturing industries. The second dataset (PROWESS 3.1) offers all the information contained in the balance sheet and annual report of the public limited companies including data on the foreign equity holding. The study has used firm level and product level information data for empirical investigation. This information is consistent with the 3 digit National Industrial Classification

To measure the degree of concentration, paper has used product level information because it provided clear picture about the changing degree of industrial concentration in Indian manufacturing industry (for detail, refer Singh, 2009)7. The time span covered in this study is limited from 2001-02 to 2006-07 because CMIE did not provide firm level information on foreign equity before the reference period. Paper has taken the International Monetary Fund (IMF) definition to define foreign firms. According to IMF, a firm holding 10 percent or more foreign equity to total equity is considered as the foreign firm.

Concentration Measures: The present study adopted N-firm concentration ratio $\left(\mathrm{CR}_{\mathrm{n}}\right)$ as a measure of market concentration. $\mathrm{CR}_{\mathrm{n}}{ }^{8}$ is the proportion of industry's output captured by large $\mathrm{N}$-firms. Symbolically

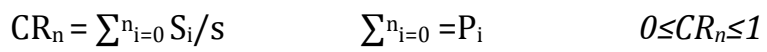

Here, $\mathrm{n}=3^{9}$

$\mathrm{S}$ is the total industry output; $S_{\mathrm{i}}$ is the sale of $\mathrm{i}^{\text {th }}$ firm and Pi is the output share of $\mathrm{i}$ firm in the total industry output.

\section{Hypothesis and Variable Construction}

Drawing inferences from the literature on FDI and market structure, paper has developed following hypothesis for empirical verification. 
Foreign Presence: It is generally accepted that the MNCs possessed the ownership advantages ${ }^{10}$ and other strategic factors that assisted them not only to produce and sell low cost products but also to establish themselves as the leading players in the host country's market. Therefore, it is hypothesized that the foreign presence and industrial concentration in host developing economy are positively correlated. Thus, the expected sign of this coefficient is positive. The present paper defined the foreign presence as the sales share of foreign firms to total sales of the industry (Driffield, 2001).

\section{Foreign Presence $=$ Sales of foreign firms $/$ Total Industry sales}

Growth Rate of Market/Industry (GRM): Curry and George (1983) and other scholars argued that the growth of an industry played an important role in changing the degree of industrial concentration. In the early stage of the life cycle of a product, there are only a few producers producing products in the market due to lack of demand and other factors. Overtime, if industry starts growing at high rate, it attracts new producers to enter the market. If it is the successful small firms that grow at a faster rate than that of their competitors ${ }^{11}$ then the new entrants will affect the dominant position of incumbents and consequently market concentration will decline. On the contrary if the existing large firms are growing faster during the booming phase of industry demand, the industrial concentration could increase further (Jeong and Masson, 1990, Kambhampati, 1998). Thus, the expected sign of the coefficient is positive which means that the industrial concentration and GRM is positively associated. GRM is defined as the proportionate change in the sales value over the period. To remove the price effect, we have deflated sales with wholesale price index of the respective industry.

Here, MS = Market Size.

$$
G R M=\left(M S_{i t}-M S_{i t-1}\right) / M S_{i t-1}
$$

Capital Intensity (CI): Capital intensity tells about the choice of technique of the firm. Higher capital intensity may work as barriers to entry for new entrants because new entrants may fail to raise the minimum amount of capital that is necessary to achieve efficient production point (Lall, 1979; Basant and Saha, 2005). On this basis, this paper hypothesizes a positive association between capital intensity and market concentration. It is defined as the ratio of fixed capital to output rather than direct capital-labour ratio due to the absence of information on number of labour or labour time employed in the data-set used for the study ${ }^{12}$.

\section{Capital Intensity = Capital Employed / Total Output}

Import Intensity: it plays a decisive role in shaping the industrial structure in a liberalized economy. As trade theorists argued, if economy is liberalized then the market forces will automatically bring competitive outcomes. Some empirical studies have supported the direct association between the import and product market competition (Krishna and Mitra, 1998) whereas others have rejected this argument empirically (Pant and Pattanayak, 2005).This variable is captured by dividing the import of commodities to the total sales of respective industry.

$$
\text { Import Intensity = Industry Imports / Total Industry Sales }
$$

Export Intensity: It is an important variable in determining the changing level of concentration in the context of a liberalized economy. In a liberalized economy, export helps the existing firms to exploit economies of scale even when domestic demand does not allow to do so. In addition, the external competition will force the local firms to improve the product quality as well as to reduce the cost of production by improving the existing techniques of production. However, if export demand is more elastic than domestic demand then an expansion of export will cause an increase in domestic prices and subsequently exporting firms may realize monopoly gain (Bourlakis, 1987; Basant and Saha, 2005). The influence of exports will be captured by export intensity defined as the share of exports in total sales of a product or industry.

$$
\text { Export Intensity = Exports of the Industry/ Total Sales }
$$

Vertical Integration: Vertical integration facilitates the firms to ensure the market for final products and to be cost effective by internalizing the inputs market uncertainty (or market imperfections). In this respect, new firms face barriers arising out of cost difference in case of entering vertically integrated industry (Basant 
and Saha, 2005). Contrary to this argument, Caves (1996) suggests that vertical integration of foreign firms would have positive effect on increasing competition because it maintains the proper functioning of market by reducing the risk of market failure. Therefore, we expect the negative impact of vertical integration on industrial concentration. For empirical analysis, vertical integration is calculated by dividing the gross value added to total sale of the industry.

\section{Vertical Integration $=$ Gross Value Added $/$ Total Sales}

Marketing Intensity: Market intensity is a part of sunk cost. High sunk cost acts as a barrier to entry (Sutton, 1991, 1998). MNCs invest heavily on advertisement and other post sales services to make their product unique in the market ${ }^{13}$. As firms are able to make their product unique, the elasticity of that product will decline and thus firms can charge price above the competitive price. Therefore, the marketing strategy in some firms is so powerful that it helps them to maintain their market share. On the other hand, some empirical studies infer that advertisement reduces market concentration by improving the consumer awareness about product alternatives and prices (Kambhampati, 1996; Atherya and Kapur, 2006). Therefore, the predicted relationship between marketing intensity and entry barriers is not certain. Hence, it is defined as the ratio of sum of expenditure on advertisement and selling including distributional expenditure and promotional expenditure to total firm sales.

\section{Marketing Intensity = Marketing Expenditure / Total Sales}

Innovative Efforts: As Schumpeter hypothesized, the firms are investing more and more for innovation to obtain exclusive knowledge and further to get monopoly power and economic profits. The study by Orr (1974); Sutton (1991) and Driffield (2001) showed that research and development intensity worked as barriers to entry for new entrants in the industry. This is especially so in case of industries characterized by high science and technology base with shorter product life cycle. Here, innovation efforts ${ }^{14}$ is described as the sum of in-house research and development (R\&D) (both capital and current) and technology purchased to total sales. The expected impact of this relation on industrial concentration is positive.

\section{Innovative Efforts = Expenditure on Innovation / Total Sales}

Rate of Return to Capital Employed (ROCE): It gives the efficiency with which capital is utilized. The decision of entry and exit is influenced by the performance of the industry (Siegfried and Evans, 1994). They suggested that expected profitability of the firms attract new entrants. Literature on this issue indicated the positive association between profitability and market concentration ${ }^{15}$. Therefore, the expected sign of coefficient is positive. For empirical analysis, it can be estimated as the proportion of profit before interest and tax divided by the amount of capital (Beena, 2006; Basant and Saha, 2005).

Here, $P B I T=$ Profit before Interest and Tax

$$
\text { ROCE }=\text { PBIT } / \text { Capital Employed }
$$

Scale Economies: Scale economies may impede entry if potential entrants have to enter with large output in order to take advantages of scale economies. The empirical studies on scale economies have reported varying results (Orr, 1974; Jeong and Masson, 1990) ${ }^{16}$. This variable is estimated as the average size of the largest firms accounting for $50 \%$ of total assets in an industry expressed as a percentage of total sector assets (Lall, 1979; Bourlakis, 1987).

\section{Scale Economies = Average Size of the Largest Firms Accounting for 50\% of a Sector's Total Assets $/$ Total Sector} Asset

Econometric Analysis: Based on previously mentioned discussion the following model has been specified to explore the bearing of foreign presence on market structure in India's manufacturing sector by controlling the impact of some of other variables. 
Model

Where,

$C R 3_{\text {it }}=\alpha_{i}+\beta_{1} \mathrm{FS}_{\text {it }}+\beta_{2} \mathrm{MI}_{\text {it }}+\beta_{3} \mathrm{EI}_{\text {it }}+\beta_{4} \mathrm{VI}_{\text {it }}+\beta_{5} \mathrm{CI}_{\text {it }}+\beta_{6} \mathrm{MKTI}_{\text {it }}+\beta_{7} \mathrm{IE}_{\text {it }}+\beta_{8} \mathrm{ROCE}_{\text {it }}+\beta_{9} \mathrm{SE}_{\text {it }}+\beta_{9} \mathrm{GRM}_{\text {it }}+\mathrm{u}_{\text {it }}$

CR3it $=$ Three Firms Concentration Ratio.

$\mathrm{FS}_{\text {it }}=$ Sales Share of Foreign Firms in $\mathrm{i}^{\text {th }}$ Industry in $\mathrm{t}$ time period.

$\mathrm{MI}_{i t}=$ Import Intensity of $\mathrm{i}^{\text {th }}$ Industry in $\mathrm{t}$ time period.

$\mathrm{EI}_{i t}=$ Export Intensity of $\mathrm{i}^{\text {th }}$ Industry in $\mathrm{t}$ time period.

$\mathrm{VI}_{\text {it }}=$ Vertical Integration of $\mathrm{i}^{\text {th }}$ Industry in $\mathrm{t}$ time period.

$\mathrm{CI}_{i t}=$ Capital Intensity of $\mathrm{i}^{\text {th }}$ Industry in $\mathrm{t}$ time period.

MKTI $_{\text {it }}=$ Marketing Intensity of $i^{\text {th }}$ Industry in $t$ time period.

$\mathrm{IE}_{\mathrm{it}}=$ Innovative Efforts of $\mathrm{i}^{\text {th }}$ Industry in $\mathrm{t}$ time period.

ROCE $_{i t}=$ Rate of Returns to Capital Employed of $\mathrm{i}^{\text {th }}$ Industry in $\mathrm{t}$ time period.

$\mathrm{SE}_{\mathrm{it}}=$ Scale Economies of $\mathrm{i}^{\text {th }}$ Industry in $\mathrm{t}$ time period.

$\mathrm{GRM}_{\mathrm{it}}=$ Growth rate of the market of $\mathrm{i}^{\text {th }}$ Industry in $\mathrm{t}$ time period.

$\beta$ 's = Coefficient of Variables.

$\alpha_{i}=$ the individual effect for the $i^{\text {th }}$ industry assumed to be constant over time.

$\mathrm{u}_{\text {it }}=$ Error/disturbance Term.

Using 1241 observations from a balanced panel, paper has estimated both pooled and panel regression models ${ }^{17}$. We used the Breusch and Pagan ${ }^{18}$ and Hausman test ${ }^{19}$ for checking whether different model specifications can be carried out under fixed effects or random effects. Using these specifications, our findings, in terms of the value of the $\mathrm{Chi}^{2}$ statistic, suggested fixed effect model is more appropriate for empirical application. The robust estimates are presented in order to deal with heteroscedasticity problem. Further, we found pair-wise correlation coefficients between explanatory variables for checking the degree of multicollinearity (see appendix, Table A1). In general, the correlation coefficient across all the independent variables is not very high. This ensures that the problem of multicollinearity does not pose a major challenge. Statistical Summary of all the variables have been presented in table A2 (See appendix).

\section{Empirical Results}

The result obtained from three models is shown in Table 1 . The estimated model is robust given the significance of $\mathrm{F}$ - values for OLS and fixed effect model and Wald Chi square values for random effect. The explanatory power (i.e. $\mathrm{R}^{2}$ ) of the model is 0.23 for fixed effect model, which is quite satisfactory in case of panel analysis. Given the model specifications, paper presents results based on fixed effect model. The finding suggests that there is positive and significant impact of foreign presence on industrial concentration. It means that the foreign presence has enhanced the levels of concentration in the Indian manufacturing sector, that is, a unit change in foreign presence leads to an increase industrial market concentration by 24.9 per cent. It is so because the domestic manufacturing firms' fail to build and maintain competitiveness needed to meet the globalization challenges (NMCC, 2006). In the absence of required competitive base, it is difficult for local firms to learn from MNCs and improve their competitiveness. In these cases, instead of building linkages and bringing new technology MNCs use anti competitive methods ${ }^{20}$ to enhance their market power and thereby to promote concentration. Our results are consistent with some of the existing studies that have found the positive association between FDI and industrial concentration (Lall, 1979; Wilmore, 1989; Blomstrom, 1986; Peria and Mody, 2004).

The export intensity also shows the positive and significant impact on industrial concentration. The possible explanation is that the exporting firms can produce quality and low cost products in order to keep them internationally competitive. Thereby, it may generate the barriers for new entrants due to the lack of competitiveness of new comers. Similar results have been noticed in earlier studies (Bourlakis, 1987; Pant and Pattanayak, 2005). Further, the innovative efforts of the firms turn as positive and significant determination of market concentration. It is so because the higher expenditure on innovative activities provides new and exclusive knowledge to the firms about production methods and helps to learn more from other firms in the market. Therefore, the innovative efforts of successful firms and market concentration are positively associated (Schumpeter, 1950). 
Table 1: Market Concentration and FDI: Estimation Results

\begin{tabular}{|c|c|c|c|}
\hline $\begin{array}{c}\text { Dependent Variable: } \mathrm{C} \\
\text { Independent } \\
\text { Variables }\end{array}$ & $\begin{array}{l}\text { Pooled OLS with } \\
\text { Robust Estimation } \\
\text { (Coefficient t-value) }\end{array}$ & $\begin{array}{l}\text { Fixed Effect Model } \\
\text { (Coefficient t-value) }\end{array}$ & $\begin{array}{l}\text { Random Effect Model } \\
\text { (Coefficient z-value) }\end{array}$ \\
\hline FS & $\begin{array}{l}0.287^{* * *} \\
(9.17)\end{array}$ & $\begin{array}{c}0.249^{* * *} \\
(4.42)\end{array}$ & $\begin{array}{l}0.259^{* * *} \\
(5.91)\end{array}$ \\
\hline MI & $\begin{array}{c}0.059^{* * *} \\
(9.18)\end{array}$ & $\begin{array}{l}0.008 \\
(1.28)\end{array}$ & $\begin{array}{c}0.013^{* *} \\
(2.23)\end{array}$ \\
\hline EI & $\begin{array}{c}-0.073^{* * *} \\
(-7.94)\end{array}$ & $\begin{array}{l}0.091^{* * *} \\
(5.18)\end{array}$ & $\begin{array}{c}0.062^{* * *} \\
(3.99)\end{array}$ \\
\hline VI & $\begin{array}{l}0.061 \\
(0.75)\end{array}$ & $\begin{array}{l}-0.007 \\
(-0.17)\end{array}$ & $\begin{array}{l}0.002 \\
(0.05)\end{array}$ \\
\hline $\mathrm{CI}$ & $\begin{array}{l}0.039 * * \\
(2.22)\end{array}$ & $\begin{array}{c}-0.112^{* * *} \\
(-5.97)\end{array}$ & $\begin{array}{c}-0.097^{* * *} \\
(-5.29)\end{array}$ \\
\hline MKTI & $\begin{array}{l}-0.039 \\
(-0.20)\end{array}$ & $\begin{array}{l}0.413 \\
(1.34)\end{array}$ & $\begin{array}{l}0.341 \\
(1.27)\end{array}$ \\
\hline IE & $\begin{array}{c}-0.789 * * * \\
(-3.97)\end{array}$ & $\begin{array}{l}0.674^{* * * *} \\
(5.17)\end{array}$ & $\begin{array}{c}0.608^{* * *} \\
(3.90)\end{array}$ \\
\hline ROCE & $\begin{array}{l}0.006^{* * *} \\
(3.24)\end{array}$ & $\begin{array}{l}0.004^{* * *} \\
(3.81)\end{array}$ & $\begin{array}{l}0.004^{* * *} \\
(3.19)\end{array}$ \\
\hline SE & $\begin{array}{c}0.002^{* * *} \\
(2.85)\end{array}$ & $\begin{array}{l}-0.001 \\
(-1.52)\end{array}$ & $\begin{array}{l}-0.000 \\
(-1.13)\end{array}$ \\
\hline GRM & $\begin{array}{c}0.194^{* * *} \\
(4.15)\end{array}$ & $\begin{array}{l}0.049^{* *} \\
(2.34)\end{array}$ & $\begin{array}{l}0.052^{* *} \\
(2.37)\end{array}$ \\
\hline A & $\begin{array}{l}0.575^{* * *} \\
(22.59)\end{array}$ & $\begin{array}{l}0.640^{* * *} \\
(26.47)\end{array}$ & $\begin{array}{c}0.637^{* * *} \\
(22.64)\end{array}$ \\
\hline No. of Observations & 1241 & 1241 & 1241 \\
\hline F Statistics & 27.79 & 18.16 & \\
\hline Prob $>$ F & 0.000 & 0.000 & 0.000 \\
\hline Wald chi & - & - & 161.25 \\
\hline $\begin{array}{l}\text { Lagrangian multiplier } \\
\text { test }\end{array}$ & & & $\begin{array}{c}\chi^{2}=2298.51 \\
(p=0.000)\end{array}$ \\
\hline $\begin{array}{l}\text { Hausman Specification } \\
\text { Test }\end{array}$ & - & \multicolumn{2}{|c|}{$\begin{aligned} \chi^{2} & =30.06 \\
(p & =0.001)\end{aligned}$} \\
\hline $\mathrm{R}^{2}$ & 0.110 & 0.226 & 0.223 \\
\hline
\end{tabular}

Source: Compiled from various issues of CMIE, industry, market size and share; CMIE PROWESS.

Note: (i) *,** and ${ }^{* * *}$ represent significant level at 10 percent, 5 percent and 1 percent respectively.

(ii)The figure in brackets represents the $t$ and $z$ values.

The coefficient of rate of return to capital employed has shown positive and significant impact on industrial concentration (refer Table 1). It signifies the direct association between the level of profits and market concentration. The higher level of concentration enables the firms to charge higher price and produce lower output than the competitive market and subsequently to realize economic profits. This finding is consistent with the existing literature (Mann, 1966; Beena, 2004). Similarly, the relationship between growth rate of market and degree of market concentration in manufacturing sector is positively linked. In the expansionary phase of industrial growth, the existing players are more likely to grow faster than the small and potential entrants in growing industry. It is so because the existing large firms have easy access to essential inputs and good network with buyers and suppliers in the market compared to the new entrants and small firms. Thus, the existing market leaders are more likely to expand their output with rising market demand. The earlier studies by Lall (1979); Cho (1990); Jeong and Masson (1990) also came-up with similar findings. 
Further, the capital intensity emerges as statistically significant variable with negative coefficient sign (Table 1). It illustrates that one unit change in capital intensity reduces the level of market concentration by 11.2 per cent. This is in contrast to some earlier studies (Lall, 1979; Driffield, 2001 etc). This apparently surprising result can be explained in context of liberalized economy. In an open economy, producers can raise capital both from domestic as well as from international capital market. As a result, the capital intensity no longer acts as an entry barrier for potential entrants in the market. The study by Cho (1990) found similar relationship between capital intensity and market concentration in Indonesia. Other variables used for empirical exercise like import intensity, marketing intensity, vertical integration and scale economies do not play a significant role in shaping the industrial market structure in the post liberalization era.

\section{Concluding Remarks}

Today the developing countries are competing against each other to attract FDI. But the impact of FDI on the host country especially its influence on domestic market concentration in India appears to have not received the attention of scholars that it deserves despite its high relevance for informed policy making. The literature on FDI and market structure across different countries, however, did not show consistent results. While one set of studies suggested that the FDI inflows reduced domestic market concentration, others found the relationship positive. In this context, the present paper is an attempt to examine the role of FDI in determining the market structure in India's manufacturing sector in the background of economic reforms. The study made use of a panel data set using 1241 observations and estimated the fixed effect model. The estimates of the econometric model revealed a positive and significant influence of FDI on market concentration in India's manufacturing sector. It suggests that the FDI inflows played an instrumental role in promoting market concentration in Indian manufacturing sector in the post reform period. Along with FDI the factors such as innovation intensity, export intensity, growth of market and rate of return to capital employed turned out to be positive and significant but capital intensity is found having a negative influence on market concentration.

Given the validity of our findings, it is clear that the rising FDI inflows are positively associated with industrial market concentration. Concentration is often seen as a deviation from competition. Therefore, the rising market concentration has implications on the long run growth path of an economy through its effect on the allocation of economic resources among various economic activities including innovation. Further, the increase in concentration and the resultant collusion may widen the gap between price and marginal cost of production and subsequently it reduces consumer surplus and increases deadweight loss. The findings of the study point towards the need for institutions involved in dealing with monopolies to be more vigilant.

\section{Acknowledgement}

The author is thankful to Prof. K. J. Joseph, Dr. Vinoj Abraham, Anoop Nair, Indervir Singh, Yadawendra Singh, Rajeev Sharma and Nilotpal Bal for their valuable comments and suggestions on an earlier draft of the paper. The author would like to thank the anonymous referees, who provided critical comments and positive suggestions to improve this paper. The usual disclaimer applies.

\section{End Notes}

${ }^{1}$ The optimism is owing to the gains from trade and investment. Theory tells us that trade leads to consumer surplus gains and efficient use of resources (Melitz, 2003 and Pavcnik, 2002) and foreign investment could lead to positive externalities such as various types of technology spillovers.

2In the pre-reform period, state intervention occurs at two levels in India: direct production by public sectors and regulation of private sector by state (Kambhampati, 1996).

${ }^{3}$ The definition of FDI has undergone various changes in the recent period to make FDI definition comparable at international levels. Till 2000-01, foreign equity was considered as FDI. Since 2000-01 FDI includes foreign equity, re-investment earning, and other capital \{Reserve Bank of India (RBI), Handbook of Statistics on Indian Economy 2006-07\}.

${ }^{4}$ In India, while the issue of market structure and other related aspects like its bearing on innovation (Bhaskar, 1992; Subramanian 2005) firm performance (Subramanian, 1971; Joseph, 1997; Giarratana, Pagano and Torrisi, 2003, Pant and Pattanayak, 2005; Beena, 2006) and others (Kumar, 1990; Basant and 
Saha, 2005; Nair, 2008; Pushpangadan and Shanta, 2008) have attracted the attention of scholars, the influence of FDI on market structure, despite its immense policy relevance, is yet to receive the attention that it deserved.

${ }^{5}$ The nature of industry would mean that the entry of FDI is taking place in competitive industry or already less competitive (or concentrated) industry.

${ }^{6}$ The transfer of technology from MNCs to local firms is not like a physical product transformation but it is conditioned by the absorption capacity and technological base that has already been developed by the firms through purposeful investment in innovation activities (Fu, 2008).

${ }^{7}$ The measure of market concentration at firm or industry level may be misleading because if one firm produces more than one product. In this process, the concentration in one product market may inflate the overall concentration level of the firm or industry or vice-versa (Singh, 2009).

${ }^{8}$ The value of the concentration ratio falls in the range between zero and one. If value of CR is near to zero (or negligible), it indicates perfect competition (or equal size distribution of firms in the industries) and if index value approaches to 1 means the emerging market structure is an oligopolistic market structure.

In literature, the often used measure of concentration is CR4. Here paper used CR3 because the concentration estimates is based on product levels data set. As mentioned in the main text, product level data is sample data set and in some cases it covers only three products. Given the data constraint, CR3 is used as a measure of market concentration.

${ }^{10}$ Ownership advantages include size of MNCs, scale economies in production, marketing and R and D investment, patent, vertical integration etc.

${ }^{11}$ Since large firms may be subjected to certain constraints on their maximum feasibility growth due to their large size (Caves and Porter, 1980).

${ }^{12}$ Number of earlier studies, (Newfarmer and Marsh, 1981; Lall and Mohammad, 1983; Subramanian and Joseph, 1994), have used capital output ratio as a proxy of capital intensity.

${ }^{13}$ Dolton and Hamm (1974); Athreye and Kapur (2006) have used market intensity as a proxy of product differentiation as well as barriers to entry.

${ }^{14}$ In case of developing countries wherein innovation is considered as a combined outcome of in-house

Research and Development and technology import, the innovation effort has to consider both of these factors. 15 See Beena (2004) and Basant, and Saha (2005).

${ }^{16}$ Orr (1974) found that economies of scale work as barriers to entry in Canadian manufacturing industries. Contrary to this, Jeong and Masson (1990) found no evidence of scale economy barriers.

${ }^{17}$ The pooled regression biases the estimated results upwards if significant cross-section or time fixed-effect are present (Bhalotra, 1998).

${ }^{18}$ The Breusch and Pagan Lagrangian multiplier test is used to identify whether pooled regression is consistent or not.

${ }^{19}$ The Hausman specification test verify more consistent model against less consistent because the consistent model ensures robust and reliable results (Baltagi, 2008).

${ }^{20}$ The anti competitive strategies include predatory conduct, marketing intensity etc.

\section{References}

Athreye, S., and Kapur, S. (2006). Industrial Concentration in a Liberalizing Economy: A Study of Indian Manufacturing. Journal of Development Studies, 42 (6), 981-999.

Baltagi, H., B. (2008). Econometric Analysis of Panel Data. U.K: John Wiley and Sons.

Basant, R., and Saha, S., N. (2005). Determinants of Entry in the Indian Manufacturing Sector. Working Paper No. 2005-01, Indian Institute of Management, Ahmedabad.

Beena, P., L. (2004). Towards Understanding the Merger-Wave in the Indian Corporate Sector: A Comparative Perspective. Working Paper No. 355, Centre for Development Studies, Trivandrum, Kerala.

Beena, S. (2006). Merger and Acquisition in Indian Pharmaceutical Industry: An Exploratory Analysis. M. Phil Thesis, Centre for Development Studies, Trivandrum, Kerala.

Bhaskar, V. (1992). Concentration in Indian Manufacturing, M. Phil Thesis. Centre for Development Studies, Trivandrum, Kerala. 
Blalock, G. and Gertler, P., J. (2009). How firm capabilities affect who benefits from foreign technology. Journal of Development Economics, 90(2), 192-199.

Blomstrom, M. (1986). Multinationals and Market Structure in Mexico. World Development, 14(4): 523-530.

Bhalotra, R. S. (1998). The Puzzle of Jobless Growth in Indian Manufacturing. Oxford Bulletin of Economics and Statistics, 60(1), 5-32.

Braunerhjelmon, P. and Oxelheim, L. (1999). Does Foreign Direct Investment Replace Home Country Investment? The Effect of European Integration on the Location of Swedish Investment. Working paper No. 522, Research Institute of Industrial Economics.

Bourlakis, C., A. (1987). Multinational Corporations and Domestic Market Structure: The Case of Greek Manufacturing Industries. Review of World Economics, 123(4), 719-733.

Caves, R. E. (1996). Multinational Enterprises and Economics Analysis. 2nd Edition, Cambridge University Press, Cambridge.

Caves, R.,E. and Porter, M., E. (1980). The Dynamics of Changing Seller Concentration, The Journal of Industrial Economics, 29(1), 1-15.

Cho, K., R. (1990). Foreign Banking Presence and Banking Market Concentration: The Case of Indonesia. Journal of Development Studies, 27(1), 98-110.

Curry, B., and George, K., D. (1983). Industrial Concentration: A Survey. The Journal of Industrial Economics, 31(3), 203-255.

Dalton, J., A. and Hamm, L., G. (1974). Growth and Product Differentiability as Factors Influencing Changes in Concentration. The Journal of Industrial Economics, 22(3), 235-240.

Driffield, N. (2001). Inward Investment and Host Country Market Structure: The Case of the U.K. Review of Industrial Organization, 18 (4), 363-378.

Dunning, J., H. and Lundan, S., M. (2008). Multinational Enterprises and the Global Economy. U.K.: Edward Elgar.

Fu, X. (2008). Foreign Direct Investment, Absorptive Capacity and Regional Innovation Capabilities: Evidence from China. Oxford Development Studies, 36(1), 89-110.

Ghosh, A. (1975). Concentration and Growth of Indian Industries 1948-68. Journal of Industrial Economics, 23(3), 203-22.

Giarratana, M.; Pagano, A. and Torrisi, S. (2003). Links between multinational firms and domestic firms: a comparison of the software industry in India. Ireland and Israel, Working Paper No. 22; LME, Italy.

Government of India. (2001). Handbook of Industrial Policy and Statistics. Department of Industrial Policy and Promotion, Ministry of Commerce and Industry, New Delhi.

Haller, S. (2004). The Impact of Multinational Entry on Domestic Market Structure and R and D. Mimeo; European University Institute.

Jeong, K., Y. and Masson, R., T. (1990). Market Structure, Entry and Performance in Korea. Review of Economic and Statistics, 72(3), 455-62.

Joseph, K.J. (1997). Industry under Economic Liberalization: The Case of Indian Electronics. New Delhi: Sage Publication.

Kambhampati, U., S. (1996). Industrial Concentration and Performance: A Study of Structure, Conduct and Performance of Indian Industry. New Delhi: Oxford University Press.

Kambhampati, U., S. (1998). Market Structure Dynamics in Indian Industry. Bulletin of Economic Research, 50 (2), 133-53.

Kindleberger, C., P. (1969). American Business Abroad: Six Lectures on Direct Investment. New Haven: Yale University Press.

Krishna, P. and Mitra, D. (1998). Trade liberalization, market discipline and productivity growth: new evidence from India. Journal of Development Economics, 56(2), 447-462.

Kumar, N. (1990). Mobility barrier and Profitability of Multinational and local enterprises in Indian manufacturing. The Journal of Industrial Economics, 38 (4), 449-463.

Lall, S. (1979). Multinational and Market Structure in an open Developing Economy: The Case of Malaysia. Review of World Economies, 115(2), 325-350.

Lall, S., and Mohammad, S. (1983): Foreign Ownership and Export Performance in Large Corporate of India. Journal of Development Studies, 20(1), 56-67. 
Lundin, N.; Sjoholm, F.; He, P. and Qian, J. (2007) FDI, Market Structure and R and D Investments in China. Working Paper No. 708, The International Centre for the Study of East Asian Development, Kitakyushu.

Mann, H., M. (1966). Seller Concentration, Barriers to Entry and Rates of Return in Thirty Industries, 19501960. The Review of Economic and Statistics, 48(3), 296-307.

Markusen, J., R. and Venables, A., J. (1997): Foreign Direct Investment as a Catalyst for Industrial Development. Working Paper No: 5696, National Bureau of Economic Research, Cambridge, Mass.

Melitz, M., J. (2003). The Impact of Trade on Intra-Industry Reallocations and Aggregate Industry Productivity. Econometrica, 71(6), 1695-1725.

Nair, A. (2008). Competition in Indian Manufacturing Industries: Identification, Analysis and Impact. M. Phil Thesis, Centre for Development Studies, Trivandrum, Kerala.

National Manufacturing Competitiveness Council (2006). The National Strategy for Manufacturing. National Manufacturing Competitiveness Council, Government of India.

Newfarmer, R. and Marsh, L. (1981). Industrial Independence and Development: A Study of International Linkage and International Performance in Brazil. Mimeo; University of Notro Dame.

Newfarmer, R. S. (1979). TNC Takeovers in Brazil: The Uneven Distribution of Benefits in the Market for Firms. World Development, 7(1), 25-43.

Orr, D. (1974). The Determinants of Entry: A Study of the Canadian Manufacturing Industries. The Review of Economics and Statistics, 56(1), 58-66.

Pant, M. and Pattanayak, M. (2005). Does Openness Promote Competition? A Case Study of Indian Manufacturing. Economic and Political Weekly, 40(39), 4226-4231.

Pavcnik, N. (2002). Trade Liberalization, Exit and Productivity Improvements: Evidence from Chilean Plants. Review of Economic Studies, 69(3), 245- 276.

Peria, M., S. and Mody, A. (2004). How Foreign Participation and Market Concentration Impact Bank Spreads: Evidence from Latin America. World Bank Policy Research Working Paper 3210, World Bank.

Petrochilos, G.A. (1989). Foreign Direct Investment and the Development Process. England: Gower Publishing Company.

Pushpangadan, K. and Shanta, N. (2008). Product Market Competition and Employment in the Organized Manufacturing Sector in India. The Indian Journal of Labour Economics, 51(3), 381-396.

Reserve Bank of India (2006). Handbook of Statistics on the Indian Economy. Annual Publication of RBI, Mumbai.

Schumpeter, J. A. (1950). Capitalism, Socialism and Democracy. $3^{\text {rd }}$ edition, New York: Harper.

Secretariat for Industrial Approval (2009). Annual Report, Department of Industrial Policy and Promotion, Ministry of Commerce, Government of India.

Siegfried, J., J. and Evans, L. B. (1994). Empirical Studies of Entry and Exit: A Survey of the Evidence. Review of Industrial Organization, 9(2), 121-155.

Singh, J. (2009). Foreign Direct Investment and Market Structure: Evidence from India's Manufacturing sector. M. Phil Thesis, Centre for Development Studies, Trivandrum, Kerala.

Subramanian, K.K. (2005). Economic Reforms Market Structure and Innovations in Indian Industry. Project Report, Centre for Development Studies, Trivandrum, Kerala.

Subramanian, K., K., and Joseph, J., K. (1994). Foreign Control and Export Intensity of Firms in Indian Industry. Working Paper No. 258, Centre for Development Studies, Thiruvandrum, Kerala.

Subramanian, K., K. (1971). Market Structure and R and D Activity: A Case of the Chemical Industry. Economic and Political Weekly, 6(35), 115-119.

Sutton, J. (1991). Sunk Costs and Market Structure: Price Competition, Advertising and the Evolution of Concentration, London: MIT Press.

Sutton, J. (1998). Technology and Market Structure: Theory and History. London: MIT Press.

Sutton, J. (2007): Quality, Trade and the Moving Window: The Globalization Process. The Economic Journal, 117(524), 469-498.

UNCTAD (United Nations Conference on Trade and Development) (1997). Transnational Corporations, Market Structure and Competition Policy. World Investment Report, Geneva and New York, United Nations. 
UNCTAD (United Nations Conference on Trade and Development) (2009). Transnational Corporations, Agricultural Production and Development. World Investment Report, Geneva and New York, United Nations.

Willmore, L. (1989). Determinants of Industrial Structure: A Brazilian Case Study. World Development, 17 (10), 1601-1617.

Yun, M. (2001). Impact of FDI on Competition in Korean Manufacturing Industries: 1991-97. Mimeo; Korea Institute for International Economic Policy

\section{Appendix}

Table A1: Correlation Matrix of Selected Variables for Analysis

\begin{tabular}{|c|c|c|c|c|c|c|c|c|c|c|c|}
\hline Variables & CR3 & FS & MI & EI & VI & CI & MKTI & IE & ROCE & SE & GRM \\
\hline CR3 & 1 & & & & & & & & & & \\
\hline FS & $0.169^{*}$ & 1 & & & & & & & & & \\
\hline MI & $0.112^{*}$ & $-0.078^{*}$ & 1 & & & & & & & & \\
\hline EI & $-0.123^{*}$ & $-0.084^{*}$ & $0.363^{*}$ & 1 & & & & & & & \\
\hline VI & 0.051 & $0.125^{*}$ & $-0.116^{*}$ & -0.048 & 1 & & & & & & \\
\hline $\mathrm{CI}$ & 0.059 & $-0.113^{*}$ & 0.017 & $-0.076^{*}$ & $0.291^{*}$ & 1 & & & & & \\
\hline MKTI & -0.021 & 0.029 & $-0.083^{*}$ & -0.064 & 0.051 & -0.053 & 1 & & & & \\
\hline IE & -0.055 & $0.150^{*}$ & -0.018 & -0.024 & $0.133^{*}$ & $0.079 *$ & 0.054 & 1 & & & \\
\hline ROCE & 0.052 & -0.003 & 0.034 & -0.01 & $0.299^{*}$ & 0.039 & -0.02 & -0.015 & 1 & & \\
\hline SE & 0.07 & $-0.108^{*}$ & -0.002 & 0.024 & -0.013 & $0.081^{*}$ & 0.044 & -0.06 & -0.006 & 1 & \\
\hline GRM & $0.128^{*}$ & 0.019 & -0.046 & -0.02 & 0.022 & -0.072 & $-0.091^{*}$ & -0.01 & -0.008 & -0.023 & 1 \\
\hline
\end{tabular}

Note: * Indicates significant at 1 percent.

Table A2: Summary Statistics of Variables used for Analysis

\begin{tabular}{lcc}
\hline Variables & Mean & Std. Dev. \\
\hline CR3 & 0.651 & 0.267 \\
FS & 0.127 & 0.179 \\
MI & 0.298 & 0.880 \\
EI & 0.260 & 0.635 \\
VI & 0.194 & 0.093 \\
CI & 0.767 & 0.437 \\
MKTI & 0.057 & 0.037 \\
IE & 0.019 & 0.028 \\
ROCE & 0.239 & 1.547 \\
SE & 2.737 & 14.743 \\
GRM & 0.055 & 0.186 \\
\hline
\end{tabular}

Source: Own calculation using CMIE Prowess. 